\title{
Pengaruh Metode Mengajar Dan Sikap Siswa Terhadap Pengetahuan Sosial
}

\author{
Nurdin \\ Universitas Indraprasta PGRI J1.. Nangka N0.58 C Tanjung Barat, Jakarta Selatan \\ e-mail: nur.albaniah@ymail.com
}

received : 11 February 2017

accepted : 10 April 2017

published : April 2017

\begin{abstract}
The influence of teaching methods and students' attitudes toward social knowledge. The article describes the results of this study the effect of teaching methods by using lecture and discussion on social knowledge based attitudes. The study was carried out experimentally with a $2 \times 2$ factorial design to the group of students at SMA Negeri 3 South Tambun, Bekasi. Datas were analyzed by analysis of variance of two lanes, and Tukey test. Based on the result of datas anaylizes, there was an interaction effect between teaching methods and students' attitudes toward social knowledge.
\end{abstract}

Keywords: teaching, lectures, discussions, student attitudes, social knowledge

\begin{abstract}
Abstrak: Pengaruh metode mengajar dan sikap siswa terhadap pengetahuan sosial. Artikel hasil penelitian ini memaparkan pengaruh metode mengajar dengan menggunakan ceramah dan diskusi terhadap pengetahuan sosial berdasarkan sikap siswa.Penelitian dilakukan secara eksperimental dengan desain faktorial $2 \times 2$ pada kelompok siswa di SMANegeri 3Tambun Selatan-Bekasi.Data dianalisis dengan analisis varians dua jalur, dan uji Tukey. Hasil penelitian mengungkap bahwa terdapat pengaruh interaksi antara metode mengajar dan sikap siswa terhadap pengetahuan sosial. Metode mengajar dengan ceramah lebih baik dipergunakan pada kelompok siswa dengan sikap tinggi, dan metode mengajar diskusi lebih baik dipergunakan pada kelompok siswa dengan sikap rendah.
\end{abstract}

Kata kunci: mengajar, ceramah, diskusi, sikap siswa, pengetahuan sosial 


\section{PENDAHULUAN}

Manusia dituntut menpunyai kemampuau untuk berpikir menghadapi perkembangan dunia kearah globalisasi dan liberalisasi. Dalam perkembangan kehidupan manusia menghadapi tuntutan baru yaitu kemampuan untuk menghasilkan jawaban yang bervariasi sehigga manusia dapat membuat perubahan secara cepat. Kompetisi sumber daya manusia terjadi secara terbuka di seluruh dunia. Sumber daya manusia bersaing secara global dari negara ke negara lain. Kemampuan bertahan dalam persaingan sumber daya manusia hanya dimiliki oleh mereka yang memiliki keunggulan. Dalam persaingan sumber daya manusia yang sangat ketat, perubahan sosial berjalan sangat cepat dipicu oleh globalisasi informasi. Bangsa Indonesia menjadi bagian dari bangsa-bangsa di dunia mengalami globalisasi. Dalam keadaan demikian Indonesia harus mempersiapkan warganya supaya mampu bertahan ditengah persaingan dunia.Usaha persaingan tersebut dilakukan melalui penyelenggaraan pendidikan.

Pendidikan telah digunakan sebagai cara yang dilakukan untuk mempersiapkan sumber daya manusia. Pendidikan telah diterima sebagai sarana transformasi sumber daya manusia dari generasi ke generasi. Pendidikan mengusahakan agar anak didik adaptif (adjusted) dalam masyarakat dan lingkungan. Dalam kegiatannya pendidikan harus senantiasa menyesuaikan dengan dinamika kehidupan yang terus bergerak. Oleh karenanya kemampuan berpikir secara berpariasi menjadi sangat penting dalam penyelenggaraan pendidikan yang baik. Tujuan umum pendidikan ilmu pengetahuan sosial pada jenjang pendidikan menengah akas memberikan tekanan pada penataan nalar, dan pembentukan sikap siswa. Mengingat pentingnya ilmu pengetahuan sosial, maka sangat diharapkan siswa sekolah mengengah atas dapat memahami pelajaran ilmu pengetahuan sosial sebagai sarana berfikir ilmiah untuk menunjang keberhasilan dalam menempuh jenjang pendidikan yang lebih tinggi.

Kenyataan menunjukkan bahwa hasil belajar ilmu pengetahuan sosial di sekolah menengah atas masih relatif rendah. Hasil ulangan semester tujuh SMA negeri 3 Tambun SelatanBekasi tahun pelajaran 2016/2017 untuk mata pelajaran Ilmu pengetahuan sosial dengan ratarata 7,2. Keadaan ini merupakan suatu hal yang perlu diperhatikan, terutama yang menaruh perhatian kepada pendidikan ilmu pengetahuan sosial, salah satu upaya yang perlu dilakukan yaitu perlu diterapkan meode mengajar yang baik.

Tabel 1. Desain Penelitian

\begin{tabular}{|c|c|c|c|}
\hline \multirow{2}{*}{$\begin{array}{l}\text { Variabel } \\
\text { Atribut }\end{array}$} & \multirow{2}{*}{$\begin{array}{l}\text { Variabel } \\
\text { Treatment }\end{array}$} & \multicolumn{2}{|c|}{$\begin{array}{c}\text { Metode Mengajar } \\
\text { A }\end{array}$} \\
\hline & & $\begin{array}{l}\text { Ceramah } \\
\text { A1 }\end{array}$ & $\begin{array}{c}\text { Diskusi } \\
\text { A2 }\end{array}$ \\
\hline $\begin{array}{c}\text { Sikap } \\
\text { Siswa } \\
\text { B }\end{array}$ & $\begin{array}{l}\text { Tinggi } \\
\text { B1 } \\
\text { Rendah } \\
\text { B2 }\end{array}$ & A1B1 & $\mathrm{A} 2 \mathrm{~B} 1$ \\
\hline Interak & $\begin{array}{l}\mathrm{X} B \\
\end{array}$ & & \\
\hline
\end{tabular}

\section{Keterangan:}

A1B1 = kelompok belajar yang diberi metode mengajar dengan ceramah mempunyai sikap yang tinggi.

$\mathrm{A} 2 \mathrm{~B} 1=$ kelompok belajaryang diberi metode mengajar dengan diskusi mempunyai sikap yang tinggi.

A1B2 = kelompok belajar yang diberi metode mengajar dengan ceramah mempunyai sikap yang rendah.

A2B2 = kelompokbelajaryang diberi metode mengajar dengan diskusi mempunyai sikap yang rendah. 


\section{METODE}

Penelitian dilakukan secara eksperimen dengan mempergunakan desain faktorial $2 \times 2$. Variabel terikat adalah pengetahuan sosial, sedangkan variabel bebas meliputi metode mengajar sebagai variabel perlakuan, dan sikap siswa sebagai variabel atribut. Desain faktorial penelitian disajikan pada tabel 1 .

Penelitian ini dilaksanakan di SMA Negeri 3 Tambun Selatan-Bekasi Provinsi Jawa Barat selama 6 bulan, mulai bulan Juli sampai dengan bulan Desember 2016/2017. Subjek penelitian adalah kelompok siswa meliputi 80 siswa yang terdiri dari 40 siswa mempunyai sikap yang tinggi, dan 40 siswa mempunyai sikap yang rendah. Pengumpulan data mengenai pengetahuan sosial dilakukan dengan instrument tes objektif dengan pilihan jawaban Benar (B) dengan skor 1 dan Salah (S) dengan skor 0. Data dianalisis dengan mempergunakan analisis varians dua jalur ( $t w o-$ way anova), setelah terlebih dahulu memenuhi persyaratan uji normalitas dan homogenitas antar kelompok subjek penelitian, dilanjutkan dengan uji Tukey untuk mengetahui terjadinya pengaruh interaksi antara variabel independen terhadap pengetahuan sosial.

Berdasarkan uji Lilliefors pada tingkat á sebesar 0,05 menunjukkan bahwa secara keseluruhan kelompok subjek penelitian memiliki distribusi normal. Demikian pula dengan hasil uji homogenitas pada tingkat á sebesar 0,05 menunjukkan bahwa secara keseluruhan kelompok subjek penelitian memiliki varians yang tidak berbeda.

Tabel 2. Ringkasan Analisis Varians dua jalur

\begin{tabular}{lccllcc}
\hline Sumber Varians & Dk & JK & RJK & $\mathbf{F}_{\mathbf{h}}$ & $\mathbf{F}_{\mathbf{t}}$ & $\mathbf{F}_{\mathbf{t}}$ \\
\hline & \multicolumn{7}{c}{} & & & $\alpha=0.05$ & $\alpha=0,01$ \\
Antar Kolom (A) & 1 & 14,73 & 14,73 & $7,65^{*}$ & 3,85 & 2,17 \\
Antar Baris (B) & 1 & 8,57 & 8,57 & 3,95 & 3,85 & 2,17 \\
Interaksi ( A x B) & 1 & 183,91 & 183,91 & $42,98^{* *}$ & 3,85 & 2,17 \\
$\quad$ Dalam & 76 & 478 & 4,88 & & & \\
\hline$\quad$ Total & 79 & 602 & & & \\
\hline Keterangan : &
\end{tabular}

\section{HASIL DAN PEMBAHASAN}

Secara keseluruhan pengetahuan sosial pada siswa yang diberi metode mengajar diskusi lebih tinggi dari pada pengetahuan sosial yang diberi metode mengajar ceramah.

Sesuai pendapat Semiawan (1992: 76), menyatakan bahwa diskusi merupakan sarana pertukaran pikiran untuk menjelaskan suatu pendapat sampai pada suatu kesimpulan. Menurut Van den Ban dan Hawkins (1996: 141-146), diskusi tidak hanya menambah pengetahuan, tetapi juga dapat mempengaruhi terjadinya pemahaman, perubahan sikap dan perilaku, karena diskusi melibatkan proses berpikir yang sangat kompleks.Mengacu pandangan Leahy dan Harris (1991: 220-222), menyatakan pengetahuan itu terbentuk dari hasil interaksi antara stimulus dan pemikiran yang aktif serta tersimpan dalam memori (mental dictionary) seseorang. Siswa yang mengikuti pelajaran dengan metode diskusi dapat berpikir secara 
kompleks sehingga pengetahuan yang diterima lebih baik. Mengacu pendapat Santoso (2000: 81), menyatakan bahwa metode mengajar dengan ceramah yaitu cara yang dilaksanakan oleh guru dengan memberikan sejumlah informasi kepada sejumla warga didik di dalam atau di luar ruangan. Krech Crutchfiled dan Ballachey (1962: 2), mengemukakan bahwa pengetahuan seseorang adalah hasil belajar yang diorganisasikan secara selektif dari sejumlah fakta, informasi tentang prinsip-prinsip yang dimilikiny dari berbagai pengalaman. Siswa yang mengikuti pelajaran dengan meteode ceramah kurang perhatiannya sehingga pengetahuan yang diperoleh kurang maksimal.

Kelompok belajar yang mempunyai sikap tinggi pengetahuan sosial pada siswa yang diberi metode mengajar ceramah lebih tinggi dari pada pengetahuan sosial pada siswa yang diberi metode mengajar diskusi.

Hipotesis penelitian secara inferensial diuji dengan menggunakan analisis varians (ANAVA). Untuk memperjelas terjadinya interaksi, disajikan grafik.

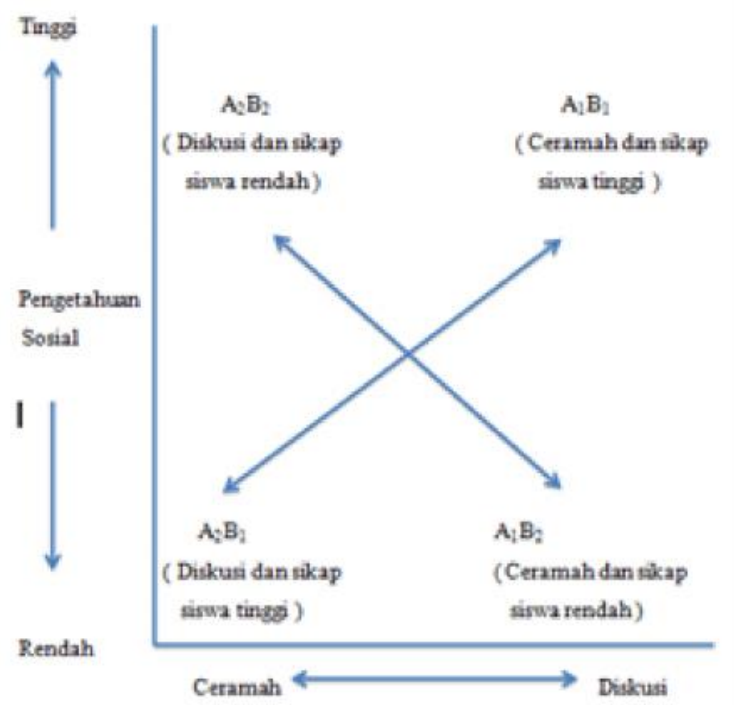

Gambar 1. Interaksi antara metode mengajar dan sikap siswa terhadap pengetahuan sosial
Mengacu pandangan Winkel (1991: 77), bahwa orang yang memiliki sikap yang tinggi mampu untuk memilih secara tegas diantara beberapa kemungkinan. Bila dihubunkan pendapat Braudy (1989:342), bahwa ceramah merupakan suatu prosedur pengajaran memberikan informasi kepada peserta ajar siap menerima instruksional belajar. Siswa yang memeliki sikap yang tinggi bila diberi pelajaran dengan ceramah mereka lebih mudah memehami materi yang diajarkan karena siswa mempunyai sikap yang positif dan bersungguh-sungguh mengikuti pelajaran. Sesuai pendapat Santoso (2000: 81), menyatakan babhwa metode ceramah merupakan cara yang dilaksanakan oleh guru dengan memberikan sejumlah informasi kepada sejumlah warga didik di dalam atau di luar ruangan. Guru berusaha memberikan selingan dengan humor supya peserta didk tidak bosan atau pasif. Siswa yang mempunyai sikap tinggi diberi metode mengajar ceramah lebih mudah menyerap materi ajar yang diberikan sehingga pengetahuannya bertambah. Mengacu pendapat Marat (1982: 13), menyatakan sikap merupakan penilaian perasaan senang atau tidak senang seseorang akan menumbuhkan kesediaan atau kesiapan untuk berbuat terhadap objek. Jadi dapat ditapsirkan bahwa siswa yang mempynyai sikap tinggi jika diajar dengan metode diskusi kurang perhatiannya karena sudah mempunyai pengetahuaan yang memadai, sehingga pengetahuannya kurang optimal.

Kelompok belajar yang memiliki sikap yang rendah pengetahuan sosial yang diberi metode mengajar ceramah lebih rendah dari pada pengetahuan sosial pada siswa yang diberi metode mengajar diskusi.

Mengacu pendapat wijaya (1992: 62), menyatakan bahwa ceramah merupakan suatu penyampaian informasi, dimana guru memberi bahan ajar di depan siswa. Myers (1988: 36), menyatakan bahwa sikap merupakan hasil penilaian seseorang terhadap suatu benda atau 
orang baik penilaian yang menyenangkan atau tidak menyenangkan yang diperlihatkan dalam kepercayaannya, perasaan dan kecenderungan untuk bertindak. Siswa yang memiliki sikap yang rendah jika diajar dengan metode ceramah perhatiannya kurang karena siswa kurang mampu menyerap materi yang diberi oleh guru, sehinga pengetahuan yang diperoleh kurang baik. Mengacu pandangan Sumarmo (1994: 17), menyatakan bahwa metode mengajar melalui diskusi dapat meningkatkan sikap positif siswa terhadap ilmu yang dipelajari dan dapat mendorong siswa untuk berpartisipasi secara aktif.

Terdapat Interaksi antara metode mengajar dengan sikap siswa terhadap pengetahuan sosial. Mengacu pendapat Suparno (2016; 70), mengemukakan bahwa mengajar berarti partisipasi dengan pebelajar dalam membentuk pengetahuan, membuat makna, mencari kejelasan, dan mengadakan justifikasi.Sesuai pandangan Baron (1992: 139), menyatakan sikap terbentuk dari pengalaman-pengalaman masa lampau terhadap suatu objek situasi dan kondisi intern disaat menerima atau mengorganisasikan informasi.Ceramah merupakan suatu metode penyampain informasi, dimana guru berbicara memberi materi ajar secara aktif dan siswa mendengarkan. Menurut Mc Keachie (1994: 57-58), penggunaan metode ceramah dapat menarik perhatian siswa dengan gerakan dan eksperesi wajah, memberikan contoh yang menggugah dan membuat suasana hidup, dan memberikan contoh kasus berkaitan dengan topik. Berkaitan hal tesebut dengan mengacu pendapat Leahy dan Harris (1991: 220222), pengetahuan terbentuk dari hasil interaksi antara stimulus dan pemikiran yang aktif serta tersimpan dalam memori (mental dictionary) seseorang. Hal tersebut dapat ditapsirkan bahwa siswa yang mempunyai sikap yang tinggi sebaiknya deberi pelajaran dengan metode ceramah, karena siswa mempunyai pengalaman yang memadai dan mudah menyerap materi yang diajarkan sehingga pengetahuannya bertambah.

Mengacu pendapat Marat (1982: 25), sikap merupakan suatu penilaian perasaan senang atau tidak senang seseorang akan menumbuhkan kesediaan atau kesiapan untuk berbuat terhadap objek. Hal tersebut dapat ditapsirkan bahwa siswa yang mempunyai sikap rendah sebaiknya diajar dengan meteode diskusi. Mengacu kembali pendapat Semiawan (1992: 76), menyatakan bahwa diskusi merupakan sarana pertukaran pikiran untuk menjelaskan suatu pendapat atau pemecahan persoalan sampai pada suatu kesimpulan atau pengertian bersama. Sesuai pendapat Bybee (2016: 70), menyatakan pembelajaran bisa meningkat ketika siswa terlibat dalam diskusi tentang ide-ide dan terlibat dalam proses. Mengacu Pendapat Pieget yang dikutip oleh Suparmo (2001: 35), mengemukakan bahwa pengetahuan tidak diterima begitu saja dari guru, tetapi murid sendiri yang harus mengorganisasi, memikirkan dan membentuk pengetahuan itu. Tanpa kegiatan secara aktif untuk membentuk pengetahuan dalam pikirannya, seseorang tidak akan tahu sesuatu. Jadi siswa yang mempunyai sikap rendah sebaiknya diberi metode mengajar diskusi karena siswa lebih aktip mengikuti pelajaran sehingga lebih muda menyerap materi yang diberikan oleh guru, sehingga pengetahuannya lebih baik.

\section{SIMPULAN}

Secara keseluruhan, pengetahuan sosial pada siswa yang diberi metode mengajar diskusi lebih tinggi dari pada pengetahaun sosial pada siswa yang diberi metode mengajar ceramah.

Kelompok belajar yang mempunyai sikap tinggi, pengetahuan sosial pada siswa yang diberi metode mengajar ceramah lebih tinggi dari pada pengetahuan sosial pada siswa yang diberi metode mengajar diskusi. Kelompok belajar yang mempunyai sikap rendah, pengetahuan sosial 
pada siswa yang diberi metode mengajar diskusi lebih tinggi dari pada pengetahuan sosial pada siswa yang diberi metode mengajar ceramah dan terdapat pengaruh interaksi antara metode mengajar dengan sikap siswa terhadap pengetahuan sosial

\section{DAFTAR RUJUKAN}

Anaroga, P. dan Sri, S.1995.Psikologi Industri dan Sosial. Jakarta: Pustaka Jaya.

Bloom, B.S.1981. Taxonomy of Educational Objetives, Book I Cognitive Domain, New York and london : Logman.

Binti, M. 2016. Jurnal Ilmiah Cakrawala Pendidikan. Yogyakarta: LPPMP Universitas Negeri Yogyakarta:177-186.

Baron, R.A. 1992.Social Psychology. Boston: Allyn and Bacon.

Broudy, H.S.1989.Building a Philosophy of Education. New Jersey: Printice Hill Inc.

Durkheim, E.1961.Moral Education. New York: Free Prees.

Gagne, R. M. 1977.The Condition of Learning. New York: by Holt, Rinehart and Winston, Inc.

Herganhahn, B.R. \& Matthew, H. O.1993. An Introduction to Theories of Learning. New Jersey: Prentice Hall, Inc.

Hudoyo, H. 1979. Pengembangan Kurikulum Matematika dan Pelaksanaannya di Depan Kelas. Surabaya: Usaha Nasional.

Jones, G.E. \& Mautice, J. R.1987. Progress in Rural Extension and Cummunity Developemen. New York: John Wiley and Sons.

Krech, D. R. S. C. \& Egerton, L. B.1962. Individual in Society. New York: McGraw-Hill Book Company.

Leahy, H. \& Richard, J. H.1971. Learning and Cognition.New Jersey: Prentice Hall Inc.

Marat. 1982.Sikap Manusia, Perubahan serta Pengukurannya. Jakarta: Ghalia Indonesia.
Myers, D.G.1988.Social Psychology. New York: McGrow-Hill Inc.

Mulier, D. J.1996. Measuring Social Attitude A Handbook for Researchers. New York: Columbia University.

Merril, M. D. 1993. Component Display Theory Instructional Design Theories and Model, New Jersey: Laurence Erlbuam Ass Publ.

Muhadjir, N. 1992. Pengukuran Kepribadian. Yogyakarta: Rake Sarasin.

McKeachie, W. J. 1994.Teaching Tips Strategies Research and Theory For College and University Teachers. Lexington: D.C. Health and Company.

Piaget, J. K.1985.The Instructional Design Process. New York: Harper \& Row.

Rapi, N. K. 2016. Jurnal Ilmiah Cakrawala Pendidikan. Yogyakarta: LPPMP Universitas Negeri Yogyakarta: 70-79 Suriasumantri, J. 2000. Filsafat Ilmu Sebuah Pengantar Populer. Jakarta: Pustaka Sinar Harapan.

Sallis, E. \& Gary, J. 2002. Knowledge Management in Education.London: Biddies Ltd.

Suparmo, P. 2001.Teori Perkembangan Kognitif. Yogyakarta: Kanisius.

Santoso, S. 2000. .Problematika Pendidikaan dan Cara Pemecahannya. Jakarta: Kreasi Pena Gading.

Sumarmo, U. 1994. Suatu Alternatif Untuk Meningkatkan Kemampuan Pemecahan Masalah Matematika pada Guru dan Siswa SMP. Bandung: IKIP Bandung.

Van, D. B. \& Hawkins. 1996. Penyuluhan Pertanian. Yogyakarta: Kanisius Sinar Harapan.

Wijaya, C.T. R.1992. Kemampuan Dasar Guru dalam Proses Belajar Mengajar. Bandung: Remaja Rosdakarya.

Winkel, W. S.1991. Psikologi Pengajaran. Jakarta: Grasindo. 